\title{
Is Eighth District Manufacturing Endangered?
}

\author{
Thomas B. Mandelbaum
}

$\mathbf{E}$ MPLOYMENT in U.S. manufacturing industries has declined more than 9 percent since 1979 , casting doubt about the stability of our industrial base. Othe" indicators of manufacturing activity, however, suggest a more favorable evaluation. Real output in manufacturing, for example, has increased 16.5 pereent since 1979. This output growth, achieved with a shrinking labor input, reflects a gain in productivity per worker. Moreover, the proportion of the nation's real GNP originating in manufacturing has remained remarkably stable over the past 40 years. ${ }^{1}$

Despite this stability at the national level, a major shift of the location of manufacturing activity among regions has occurred. While declining in the "Rust Belt," manufacturing activity has posted solid gains in the West and the "Sun Belt."' Between 1947 and 1985. the share of the nation's manufactured goods produced in the Middle Atlantic and East North Central census regions dropped from 60 to 40 percent." This decline was offset by an increase in the south and

Thomas B. Mandelbaum is an economist at the Federal Reserve Bank of St. Louis. Thomas A. Polmann provided research assistance.

For an analysis of the nation's manufacturing performance, see Tatom (1986a and 1986b). See Ott (1987) for a long-run perspective on structural changes of the U.S. economy.

aSee Crandall (1986), for an analysis of regional shifts of U.S. manufacturing.

${ }^{3}$ This statement refers to the percentage of gross value added in manufacturing. published by the U.S. Bureau of the Census in Census of Manufactures and Annual Sunvey of Manufactures. Gross value added is described in the sthaded box on the next page. The Middle Atlantic census region includes New Jersey, New York and Pennsylvania; the East North Central region includes Illinoss, Indiana, Michigar, Ohio and Wisconsin.
West from 26 percent in 1947 to 46 percent in 1985 with little change in the share contributed by New England and the West North Central states."

This article compares the performance of manufacturing in the Fighth Federal heserve District with that in the nation. Its purpose is to detemine whether regional shifts of manufacturing noted elsewhere have also occurred in the Eighth District, which is not entirely in either the Sun or Rust Belts."

\section{MANUFACTURING PERFORMANCE IN THE EIGHTH DISTRICT}

In this article, employment data and three measures of manufacturing output are used to evaluate manufacturing pefformance in the District. These three output measures are manufacturing product (MP), gross value added (GVA), and value of shipments (VS) Each indicator is described in the shaded insert on page 00. An appendix outlines the methodology used to estimate the Eighth District's MP. Several indicators of mantacturing output were used to gauge the consistency of the analysis.

\footnotetext{
${ }^{4}$ The New England region includes Connecticut, Massachusetts, Maine, New Hampshire. Rhode Istand and Vermont; the West North Central region includes lowa, Kansas, Minnesota, Missouri. Nebraska, North Dakota and South Dakota. Except for the states in the Middle Atlantic and East North Central regions the rest of the states make up the South and the West.

she Eighth Federal Reserve District includes Arkansas and parts of illinois, Indiana, Kentucky, Mississippi, Missouri and Tennessee. Due to data limitations, however, only data from Arkansas, Kentucky, Missouri and Tennessee are used in the analysis.
} 


\section{Measures of District Manufacturing Output}

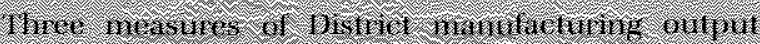

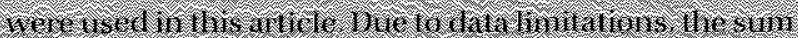

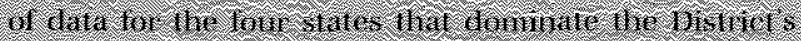

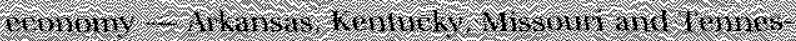

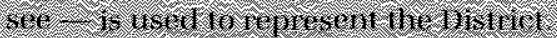

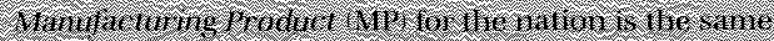

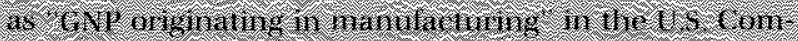

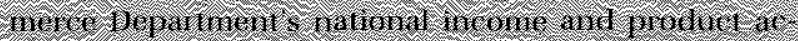

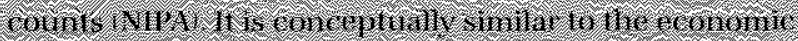

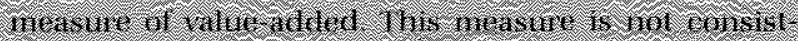

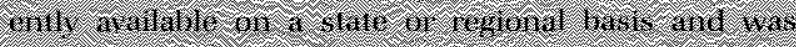

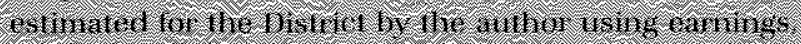

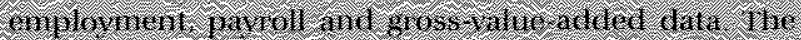

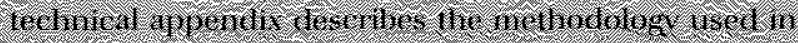

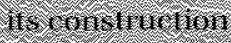

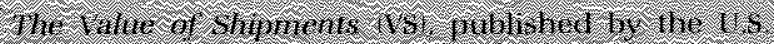

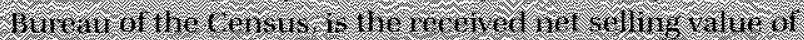

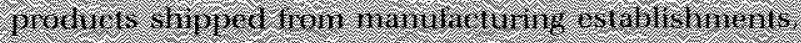

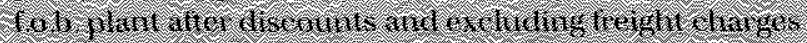

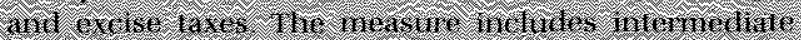

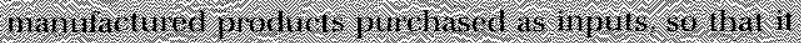

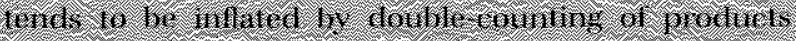

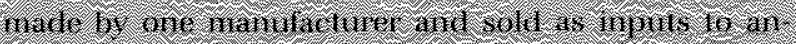

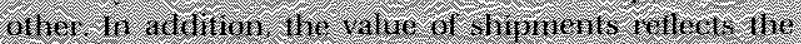

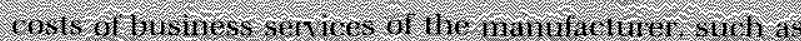

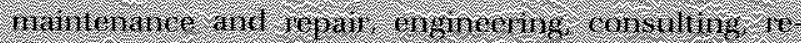

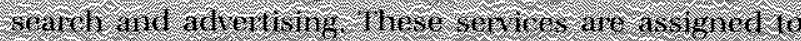

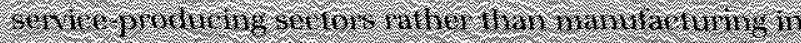

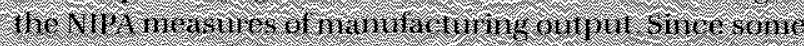

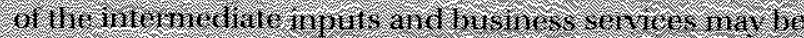

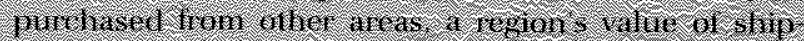

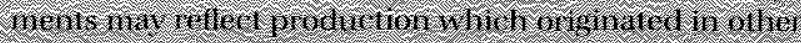
rivions

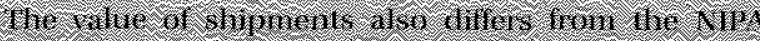

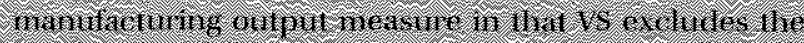

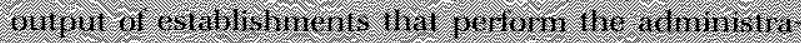

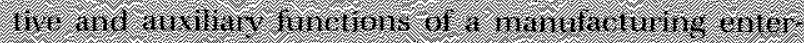

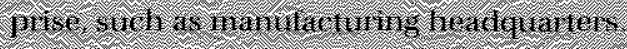

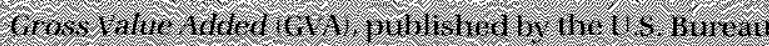

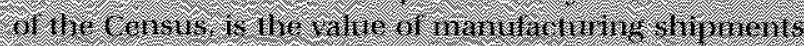

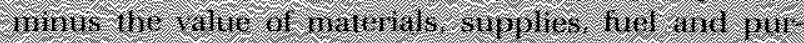

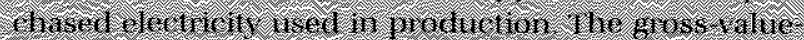

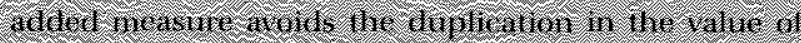

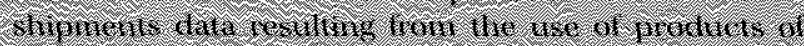

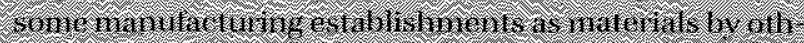

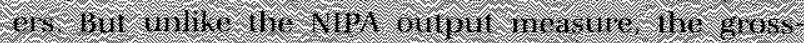

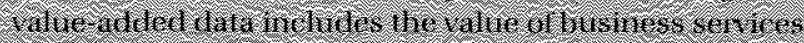

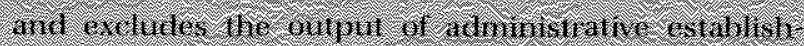
तentu.
All measures are adjusted for inflation (1982 prices) using the nation's implicit price deflator for manufacturing. Due to data limitations, the District analysis focuses on the $1972-85$ period.

\section{Manufacturing Growth: Eighth District vs. the United States}

Employment Trends. Chart 1 shows that the District's total wage and salary employment, which equals about 7 percent of U.S. total employment, closely followed movements in national employment since the early 1970 s. The similar growth of total employment in the region is not surprising; there is a close similarity between the industrial compositions of the regional and national work forces. The largest differences between the region's and nation's industrial structures are a slightly smaller proportion of the District economy accounted for by the services sector and a slightly larger share accounted for by manufac- turing." In 1986, manufacturing employed 21.4 percent of the District's wage and salary workers and 19.1 percent of the nation's.

As chart 2 shows, District manufacturing employment has also followed national trends since 1972.7 The number of manufacturing workers peaked in 1979, then declined cyclically through 1982. In the current recovery period, manufacturing employment rebounded sharply in 1984 before resuming its decline in recent years. District manufacturing employment

\footnotetext{
${ }^{6}$ See Mandelbaum (1987) for a more complete discussion of the similarities of the region's and nation's employment compositions.

A t-test of the average difference between District and U.S. annuat growth rates of manufacturing employment, 1973-85, yields a tstatistic of -0.46 , indicating the difference is not statistically significant at the .05 level. The period begins in 1973 rather than 1972 , because 1972 is the first observation and this observation is used in calculating the 1973 growth rate.
} 


\section{Chart 1}

\section{Total Employment}

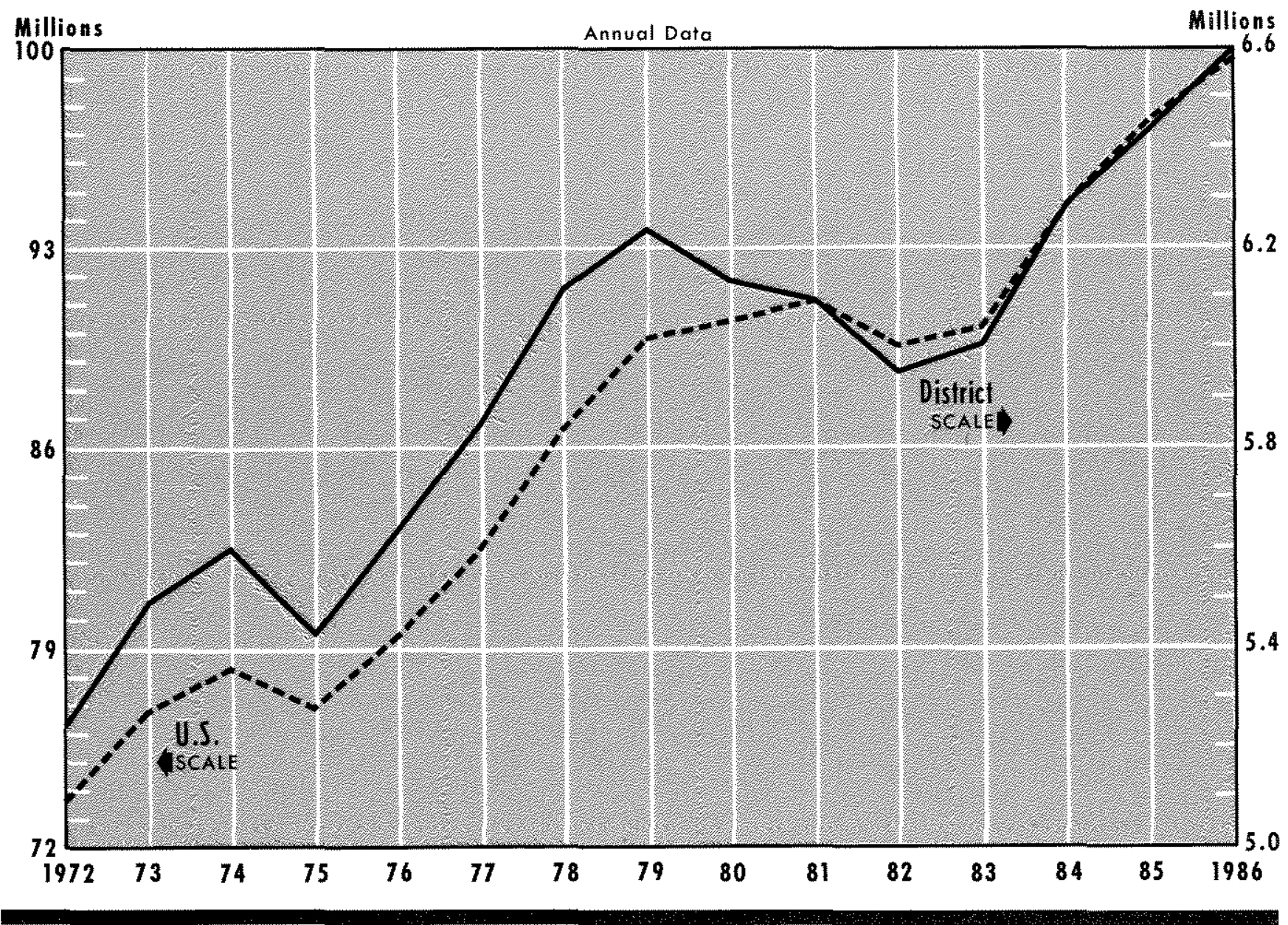

in 1986 was 1.41 million, almost 8 percent below its 1979 peak level and roughly equal to its 1972 level.

Output Growth. In contrast to employment, District manufacturing output, like that in the nation, has grown substantially. As chart 3 shows, both regional and national manufacturing output (MP) declined in fecession vears but increased sharply during business cycle uptums. The net result was a substantial output gain over the period.

The chart also shows that the District's manufacturing output has closely followed national trends. The first line of table 1 shows the close similarity between regional and national growth in various measures of output. The District's 2.6 percent average annual growth MP during the $1973-85$ period was statistically indistinguishable from the nation's 2.9 percent pace. Regardless of the output measure used, there was little difference between annual growth rates of regional and national manufacturing output."

The real value of manufacturing output in the District, as measured by MP, was $\$ 50.6$ billion 11982 prices) in 1985 . This represents a 7.5 percent gain between 1979 and 1985 , a period in which declining employment trends intensified concerns about the health of the manufacturing sector.

\footnotetext{
${ }^{9} T$-tests of the average differences between District and U.S. annual growth rates, 1973-85, of MP, GVA and VS yield t-statistics of 0.54 , -0.28 and -1.59 , respectively. None of these is significantly different than zero, in the statistical sense, at the .05 significance level.
} 
Chart 2

\section{Manufacturing Employment}

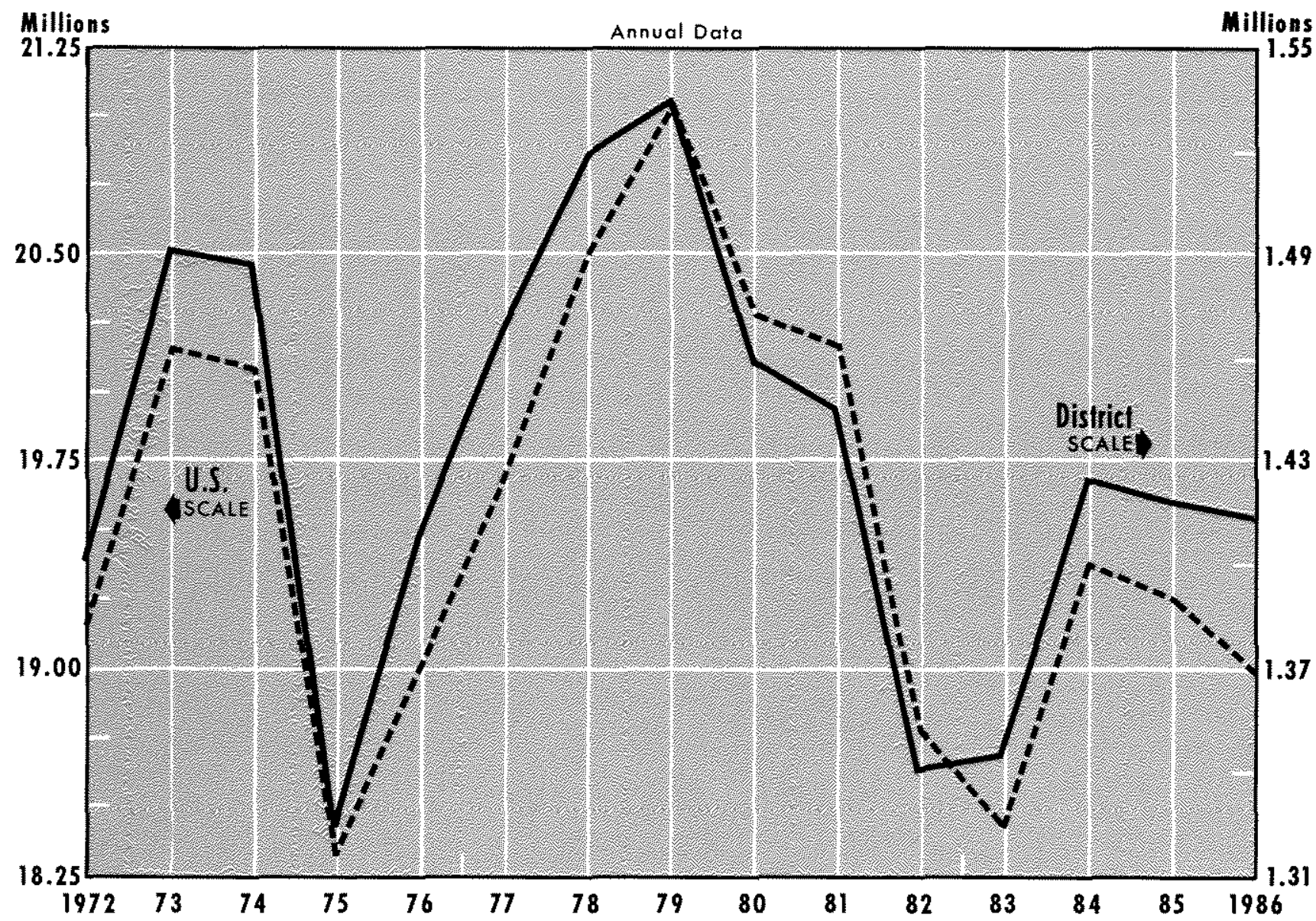

\section{Individual Industry Growth}

The similarity of manufacturing output growth in the District and the United States could mask substan. tial differences between the regional and national growth in individual industry groups. Similal growth of fotal mantacturing output could result if stronger growth of some regional subsectors offset slowerthan-national growth in others.

Each of the industy groups of the Eighth District manufacturing sector, however, grew at near the national pace. Although the growth rates of outpat for most of the District industry groups differed somewhat from the national rates lsee table 1 , none of the these differences is larger than would be expected due to the chance variation of the data." This result holds regardess of the outpul measure used.

\section{Industrial Composition}

Even with identical regional and national growth rates for ach industry, ovenall manulacturing could differ considerably if the industral compositions of

-T-tests of the average differences between District and U.S. annual growth rates for each output measure for each manufacturing industry group were conducted. None of these is statistically different from zero at the .05 level of significance. 


\section{Chart 3}

\section{Real Manufacturing Output}

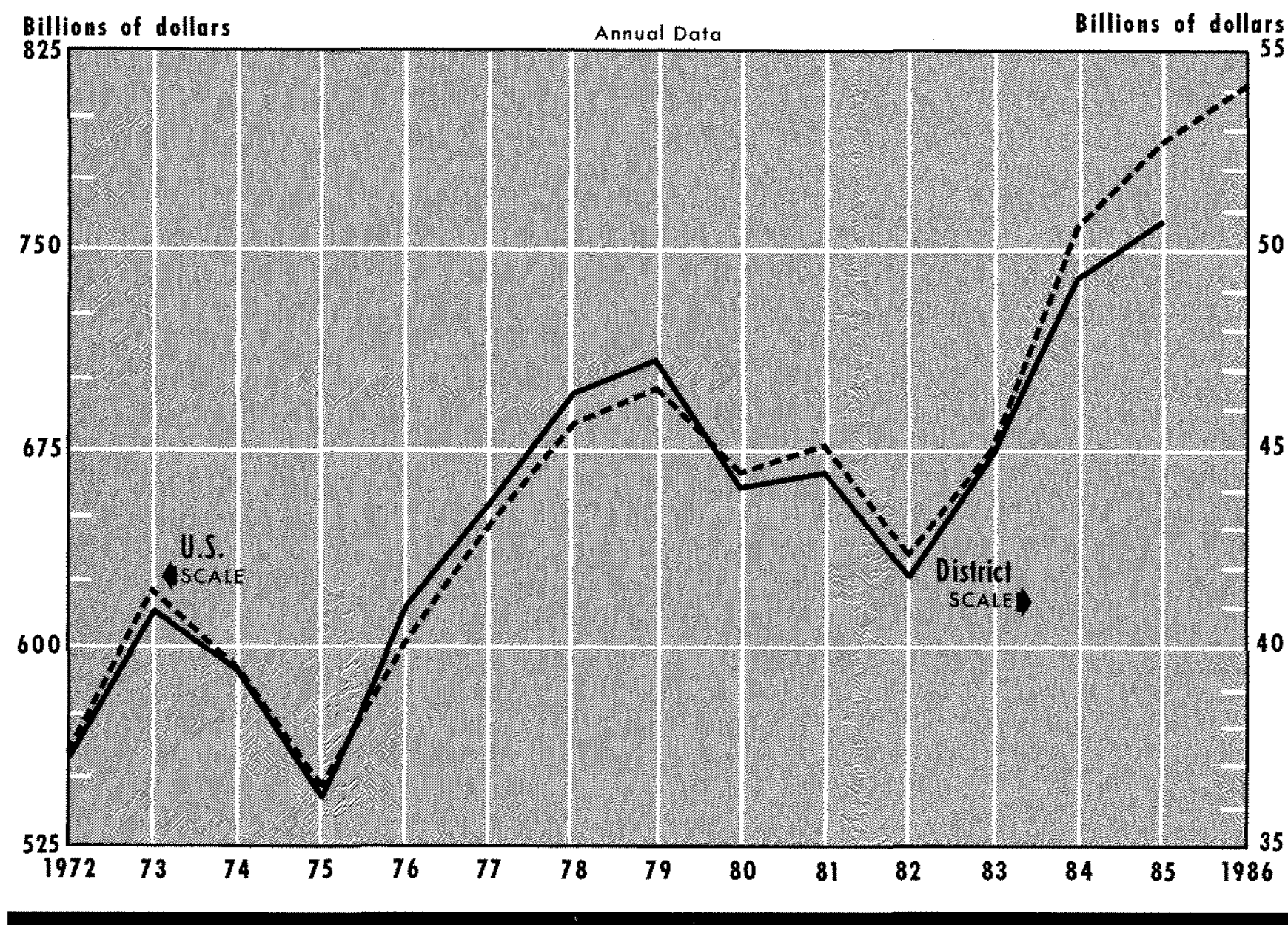

the regional and national manufacturing sectors varled substantially. For example, if legional manuacturing were concentrated in slow growing industries llike primary metal production, then the District's overall manufacturing growth would lend to thail the national expansion.

The diversification of regional and national manufacturing however, has been quite similar. Char 4 compares the percent distribution of District and U.S. manufacturing output in 1985 as indicated by MP among all the major inatustry groups. Most are of similar relative size. The sector in which the District share varied the most from the national average in 1985 was nonelectical machinem. This sector ac- counted for 14.8 percent of District Mo compared with 17.4 percent nationally, hardly a dramatic difference. Earlier data show that overall structural similarity between Dislrict and national manufacturing has exisled at least since 1972.

\section{Regional Productivity Gains}

The increases in District manuacturng output since 1972 with litte change in manufacturing enplowment imply an inclesse in lator productivity. In fact labor productivity of District manufacturing $1 \mathrm{MP}$ per mandacluring worker increased al a 2.5 percent 


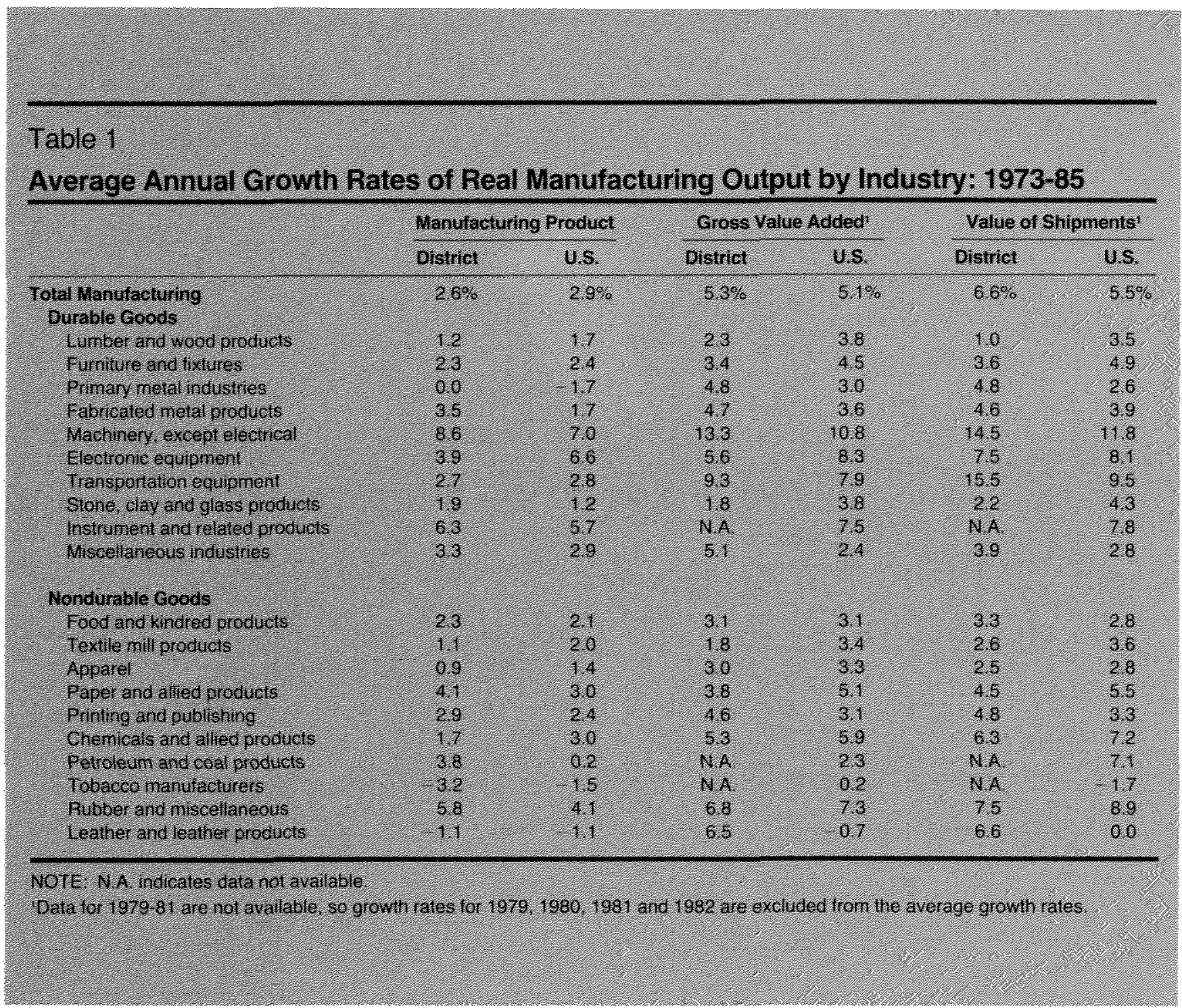

compounded annual rate between 1972 and 1985 . Table 2 shows slightly faster growth when labor productivity is measured by GVA per worker and VS per worker." ${ }^{\text {to }}$

The growth of total manulacturing output and labor productivity in the region indicate that, rather than undergoing a dramatic dechne or "deindustrializa"

\footnotetext{
10Because no regional data for GVA and VS are availabie for 1979 81 , it is impossible to compute average annual growth rates for those variables that are comparable to the average annual growth rates for MP. Therefore, compounded annual rates, which require only the initial and terminal years of the periods, are used to indicate average growth. In each productivity measure, the number of manufacturing workers are from the U.S. Bureau of the Census' Annual Survey of Manufactures and Census of Manufactures.
}

tion," the District's manufacturing sector - like the nation's - is expanding and becoming more productive.

\section{Operating Ratios}

Labor productivity and unit labor costs of a region's manufacturing sector relative to the rest of the nation are related to the region's competive position in national markets. A comparison of changes in the regional and national operating ratios reveals whether the District is keeping pace with improvements at the national level.

Table 2 compares the 1985 levels and the compounded annual growth rates of labor procuctivity 
Chart 4

\section{Composition of District and U.S. Manufacturing} Output, 1985

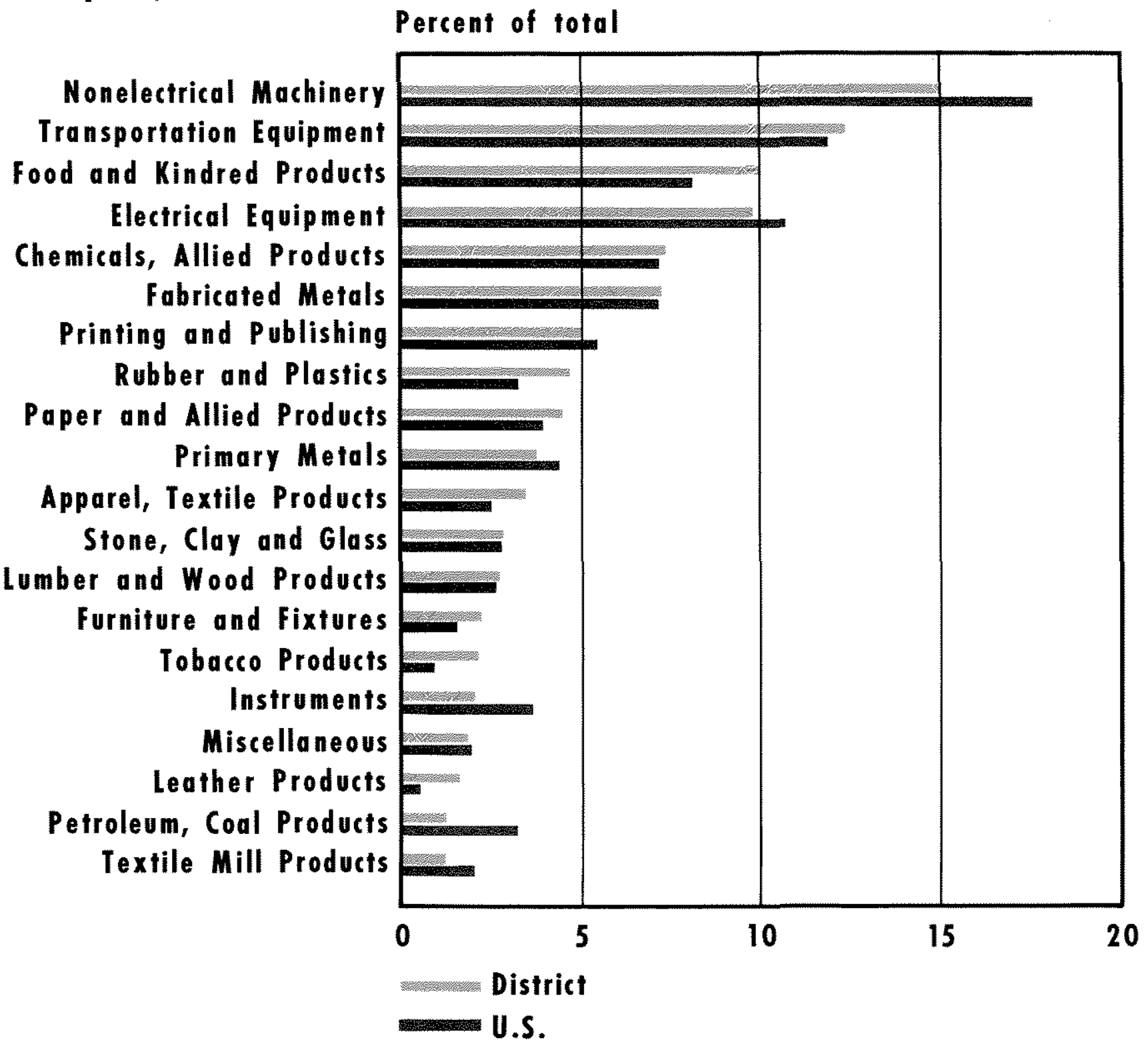

and unit labor costs using each of the three measures of output. Unit labor costs are measured by payroll per unit of otitput. "Total District payroll per dollar of MP.

"The payroll data is published by the U.S. Bureau of the Census in the Census of Manufactures and the Annual Survey of Manufactures. measured in 1982 dollars, was $\$ 0.49$, almost identical to the $\$ 0.50$ national level. In addition to similar levels,

It includes gross earnings pard to al employees, but excludes employer contributions for social insurance and payments to proprietors or partners of unincorporated establishments. 


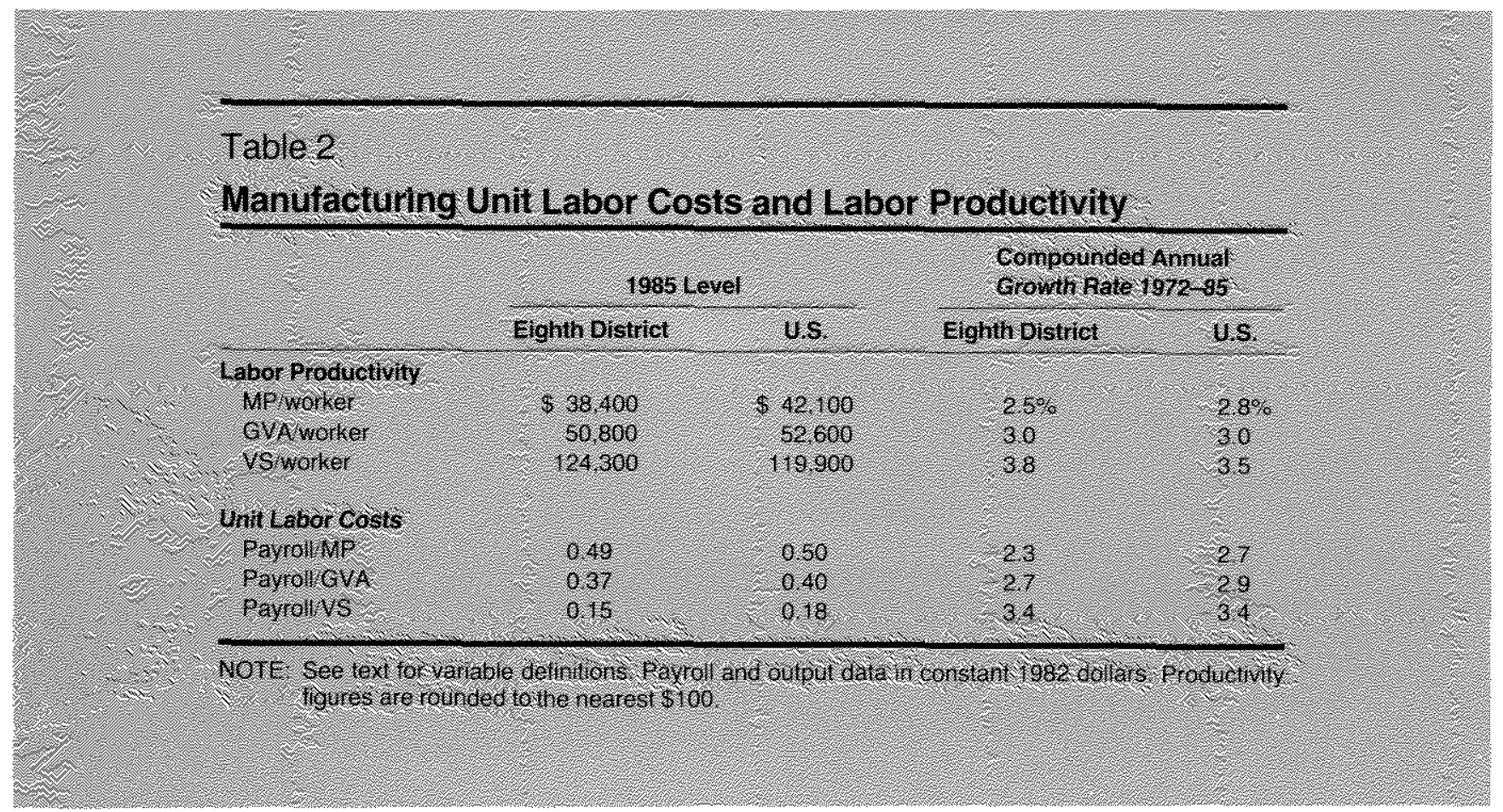

table 2 shows that the decline in District and national unit labor costs between 1972 and 1985 was also similar; unit labor costs payroll/MP) declined at a compounded annual rate of 2.3 percent in the District, and 2.7 perent rate in the nation. Similar results are found when unit labol costs are measured by payroll/GVA or payrollss.

Table 2 also shows the similarity of both the level and growth of labor productivity. Whether measured by MP/worker, GVA/worker, or VS/worker, the levels and compounded annual growth rates of District and I.S. labor productivity were quite similar.

The oveall resemblance in the levels and growt h of these operating latios suggest that District manufacturing is mantaining its competitive position relative to the rest of the nation." This, and the fact that the competitiveness of the nation's manufacturing sector has imploved relative to its major foreign competitors. suggests that District manufacturers are maintaining their competive position in intermational makets as well as in domestic ones."

\footnotetext{
12In addition to simitar composition and operating fatios, District manufacturing also resembled U.S. manufacturing in the relative importance of export industries, a factor that could influence manufacturing growth. The U.S. Census Bureau's Annual Survey of Manufactures (Origin of Exports of Manufactured Products, 1987) reponted that, in 1984, exports accounted for 5.8 percent of District manufacturing's sthipments, compared with 6.7 percent nationally.

${ }^{13}$ See Tatom (1986a), pp. 14-15.
}

\section{Uneven Growth and Structural Change}

The declining growth of some mature industries, especially metal production, is sometimes cited as an example of the decline of manufacturing. As table 1 shows, however, the growth of primary metal produc, tion is not typical of manufactuing as a whole. While the District's total MP expanded at a 2.6 percent pace in the $1973-85$ period, the average annual frowth rate of regional prinary metals output was zero. Nationally, total MP grew at a 2.9 percent rate while primary metals output fell at a 1.7 percent rate. Because the sector produced less than 10 percent of regional or national MP between 1973 and 1985 , however, its slusgist performance was offset by the more rapid growth in other manufacturing industry goups. For example, MP of the nonelectical machinery and etectronic equipment sectors grew at 8.6 and 3.9 percent rates in the District and at 7 and 6.6 percent rates nationally.

Fhese examples and the data in table 1 point out the uneven gowth among manufacturing's industry groups. Despite this diversity among the industries. growth rates, the uneven growth led to only minor changes in the industrial composition of manufacturing between 1972 and 1985 . Chat 5 shows the proportion of tolal District MP conuibuted by each of the 10 largest industry groups. Athough thene were some changes in the components of manufacturing - for example, the rapid growth of electronic equipment output catused that industry's share to increase, while 
Chart 5

\section{Composition of District Manufacturing Product, 1972-85}

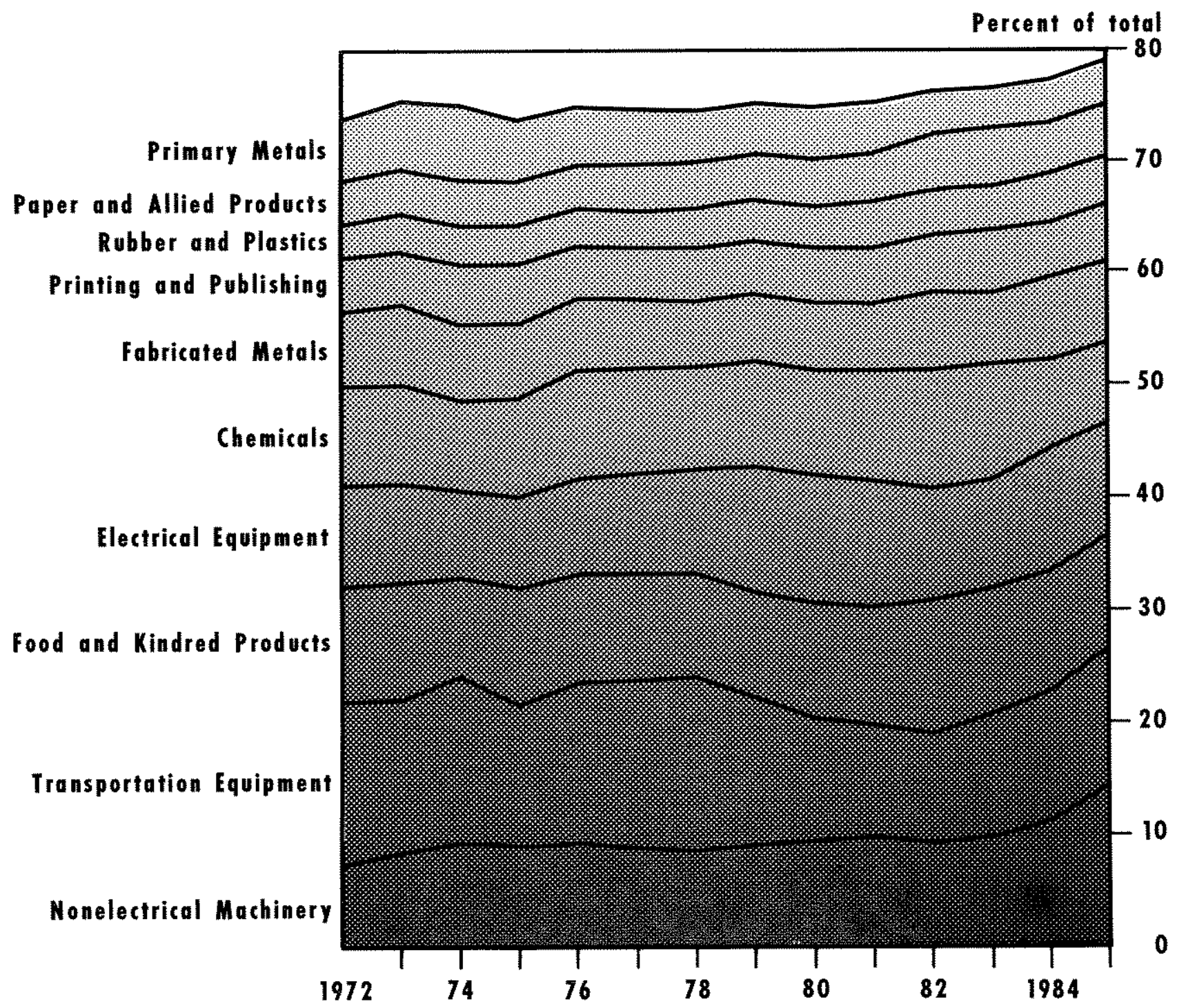

the sluggish expansion of primary metals output caused its share to shrink - overall, the composition of District manufacturing throughou this period remained velatively constant.

\section{SUMMAPU}

In both the nation and the Eighth District, employment growth in the manufacturing sector has not kept 
pace with the rest of the economy's employment growth, leading some observers to view manufacturing as an ailing industry. Output trends, however, provide a different picture of manufacturing perfor mance. Nationally, real manufacturing output has grown as fast as the other sectors of the economy. Labor productivity in manufacturing has grown faster than in the rest of the economy, allowing manufacturing to produce a constant proportion of national out put with a declining proportion of its labor force.

Not all regions shared in the nation's manufacturing stability. Rapid growth in the South and West offset declines in northern industrial areas. In the Eighth District, however, the growth of manufacturing employment and output were quite similar to the national expansion in the $1972-85$ period. This parallel growth was made possible by similarities in composition, labor productivity and unit labor costs.

Although some individual manufacturing industries contracted sharply since the early $1970 \mathrm{~s}$ in terms of real output, others grew briskly as the composition of manufacturing evolved in response to consumer demands and comparative advantage. The overall trends point to the stability and increased productiv ity of the Eighth District and U.S. manufacturing sectors.

\section{TPRTRENCES}

Crandall, Robert W. "The Transformation of U.S. Manufacturing," Industrial Felations (Spring 1986), pp. 118-30.

Kendrick, John W., and C. Milton Jaycox. "The Concept and Estimation of Gross State Product," Southern Economic Joumal (March 1965), pp. 153-68.

Mandelbaum, Thomas B. "The Eighth District's Economy: A Micro" cosm of the Nation's," Business - An Eighth District Perspective (Summer 1987).

Niemi, Albert W., Jr. "Gross State Product and Productivity in the Southeast, 1950-80," Growth and Change (April 1983), pp. 3-8.

Ott, Mack. "The Growing Share of Services in the U.S. EconomyDegeneration or Evolution?" this Review (June/July 1987), pp. 522.

Tatom, John A. "Domestic vs. International Explanations of Recent U.S. Manufacturing Developments," this Review (Apri 1986a), pp. 5-18.

Review (December 1986b), pp. 15-25.

U.S. Bureau of the Census. Annual Survey of Manufactures (Geographic Area Statistics). (GPO, various years).

Annual Survey of Manufactures, (Origin of Exports of Manufactured Products). (GPO, 1987).

Census of Manufactures (Geographic Area Statistics). (GPO, various years).

Weber, Richard E. "A Synthesis of Methods Proposed for Estimating Gross State Product," Joumal of Regional Science (March 1979), pp. 217-30. 


\section{Appendix \\ Computing District Manufacturing Product}

Manufacturing product (MP) data computed by the U.S Commerce Department measures that portion of the nahon's real GNP originating in manufacturing. No comesponding measure is avalable at the state on regional level. While the value of shipments and gross value added are related measures, the shaded insert explains how they differ from MP.

To compute a measure of District manufacturing output corresponding to national MP, the methodology developed by Kendrick and Jaycox (1965) and modified by Niemi (1983) and Weber (1979) was followed. District MP is ar estimate of the sum of manufacturing output in the four states that dominate the District economy - Arkansas, Kentucky, Missouri and Tennessee. MP was derived by estimating outpul for each of the District's 20 manufacturing industry groups and summing over all industry groups.

District MP was computed in two steps. First, preliminary estimates were calculated assuming that the ratio of output to eamings in each manufacturing industry was identical in the District and the United States. In the second step, the preliminary estimates were adjusted to correct for produc tivity differences between the District and the United States.

More specifically, the first slep in estimating District MP is to muliply the ratio of national output to national eamings in each of the industry groups by District earnings in that industry. That is, the preliminary estimate of District output originating in industry group $i$, year $t$ is:

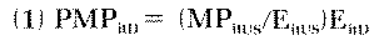

where MP is real GNP originating in the nation's manalacturing industry group i, year $t$, E represents earnings, and the US and $D$ subscripts symbolize the U.S. and the Eighth District, respectively. Eamings and U.S. MP data are published by the U.S. Commerce Department. Earnings inchude wages and salaries, other labor income and proprietory income.

The preliminary estimates resulting from equation 1 will be accurate to the extent that the matio of MP to $\mathrm{E}$ in each industry group is similar in the District and the nation. This assumption has been interpreted as one of similar productivity at the regional and national levels. In the secord step of computing District MP, the preliminary estimates for each industry group were adiusted by a measure of that industry's productivity in the District relative to the nation. This procedure was developed by Niemi 1983 . The measure of relative productivity is the ratio of gross value added per dollat of payroll for the District to gross value added per dollar of payroll in the nation, of

(2) $\left(\mathrm{GVA}_{\mathrm{ita}} / \mathrm{P}_{\mathrm{itu}} / /\left(\mathrm{GVA} \mathrm{A}_{\mathrm{it \textrm {S }}} / \mathrm{P}_{\mathrm{ins}}\right)\right.$,

where GVA and $P$ are gross value added and payroll data published by the $\circlearrowright .5$. Bureau of the Census' Annual Survey of Manufactures and the Census of Manufactures. For each industry group. the relative productivity measure was mutiplied by the preliminary estimates $\left(\mathrm{PMP}_{\text {it }}\right.$ ) 10 compute the final estimates. Total manufacturing output is the sum of the final estimates for all industry groups. 